Bangladesh J. Bot. 44(1): 73-78, 2015 (March)

\title{
ANATOMICAL CHANGES OF LENTIL (LENS CULINARIS MEDIK.) UNDER PHOSPHORUS DEFICIENCY STRESS
}

\author{
Bimal Chnadra Sarker ${ }^{1}$, Parveen Rashid and JL Karmoker \\ Department of Botany, University of Dhaka, Dhaka-1000, Bangladesh
}

Key words: Phosphorus deficiency, Anatomical changes, Lentil

\begin{abstract}
Phosphorus deficiency in lentil (Lens culinaris Medik.) resulted in the development of abundant long root hairs which were rudimentary in plants fed with phosphorus. Root and stem diameter as well as thickness of leaf reduced under phosphorus deficiency. The cortical zone of the stem and root was found to decrease under phosphorus deficiency. Vascular area became smaller with less number of xylem vessels and smaller size of the cavity due to phosphorus deficiency. The pith area was increased in the stem under phosphorus deficient condition.
\end{abstract}

\section{Introduction}

Plants have evolved to adapt to their environment. Therefore, their morphology, anatomy and physiology are likely to provide clues towards their adaptation to various growing conditions (Chandler and Bartels 2008). One of the most important inputs to agricultural systems is phosphorus (P) and the issues associated with $\mathrm{P}$ availability and acquisition by plants represent problems of global proportions (Stutter et al. 2012). Phosphorus is an essential nutrient required for plant growth and reproduction (White and Brown 2010), but due to its strong reaction with soil and subsequent lack of mobility it is estimated that $30-40 \%$ of the world's arable land is limited by P availability (Runge-Metzger 1995). Plants are profoundly affected by phosphorus deficiency because phosphorus is an indispensable constituent of nucleic acids and membrane phospholipids. Moreover, phosphorus plays a pivotal role in energy transfer, as a regulator of enzyme activity, and in signal transduction (Kavanová et al. 2006). Under P deficient conditions, however, plants have evolved several strategies to enhance $\mathrm{P}$ acquisition and reduce the need for $\mathrm{P}$ to act on multiple levels, including morphological and biochemical changes, transcriptional activation and physiological responses (Czarnecki et al. 2013).

Lentil is one of the oldest and most popular food legumes in Bangladesh. It provides a valuable and balanced protein source that, coupled with its ability to thrive on relatively marginal lands and under adverse environmental conditions, has ensured its survival as a crop. It is the second most important pulse crop in area and production, but stands first in the consumer's preference in this country (Uddin et al. 2008). It is a rich source of dietary protein and micronutrients for majority people in the country, and is consumed as a soup called 'dal' with rice (http://www.ais.gov.bd/). The productivity of the crop suffers from several biotic and abiotic factors. Very little is known about the influence of abiotic stress like phosphorus deficiency on internal morphology of lentil. So the present investigation was initiated to study the changes in anatomical structures in lentil due to phosphorus deficiency.

\section{Materials and Methods}

Lentil (Lens culinaris Medik. var. BARI Masur-4) was taken as experimental material and seeds were collected from Bangladesh Agricultural Research Institute (BARI), Joydebpur, Gazipur. Seeds were surface sterilized using sodium hypochlorite solution and plants were raised

${ }^{1}$ Department of Botany, Govt. Gurudayal College, Kishoregonj, Bangladesh. 
in pots under sand culture (Hewitt 1966) method. Modified half-strength Hoagland nutrient solution (Hoagland and Arnon 1950) containing phosphorus (+P) and no phosphorus (-P) were used to moisten the sand at regular intervals (twice in a week). The sand of $+P$ pots were moistened with $+\mathrm{P}$ nutrient solution while that of deficient pots with $-\mathrm{P}$ nutrient solution. Roots (3 $\mathrm{cm}$ below sand surface), stem segments (fourth internode) and leaves ( $7^{\text {th }}$ number) were collected from 28-day-old plants and preserved in FAA solution for anatomical study. Free hand sectioning of root, stem and leaf was done with the help of a razor blade. The sections were stained in safranin and fast green and studied with the help of a compound microscope. Micrographs of the sections were taken using a digital camera (Nikon UFY-11A, Japan) attached with microscope.

\section{Results and Discussion}

Phosphorus deficiency resulted in smaller diameter of root compared to control (Fig. 1 A, B). The most important feature is the development of abundant root hairs in phosphorus deficient condition (Fig. 1B) which is not found in control (Fig. 1A). Fohse et al. (1991) observed smaller diameter in the root of spinach under phosphorus deficiency. Li et al. (2004) reported an increase in number, length and density of root hairs in rice due to phosphorus deficiency. The epidermis of root was composed of thin-walled single layered regularly arranged cells (Fig. 1A) which are smaller and irregularly arranged in phosphorus deficient condition (Fig. 1B). The cortical parenchyma was composed of 9-10 layers of cells in +P plant while it was reduced to 7-8 layers in $-\mathrm{P}$ condition. Secondary growth was noticed in both $+\mathrm{P}$ and $-\mathrm{P}$ condition. The vascular cylinder became smaller in $-\mathrm{P}$ condition compared to $+\mathrm{P}$. Xylems vessels were less in number under $-\mathrm{P}$ condition than $+\mathrm{P}$. Liu et al. (2004) also found decreased the number of xylem vessels with smaller area in Vigna seedlings under phosphorus deficiency.

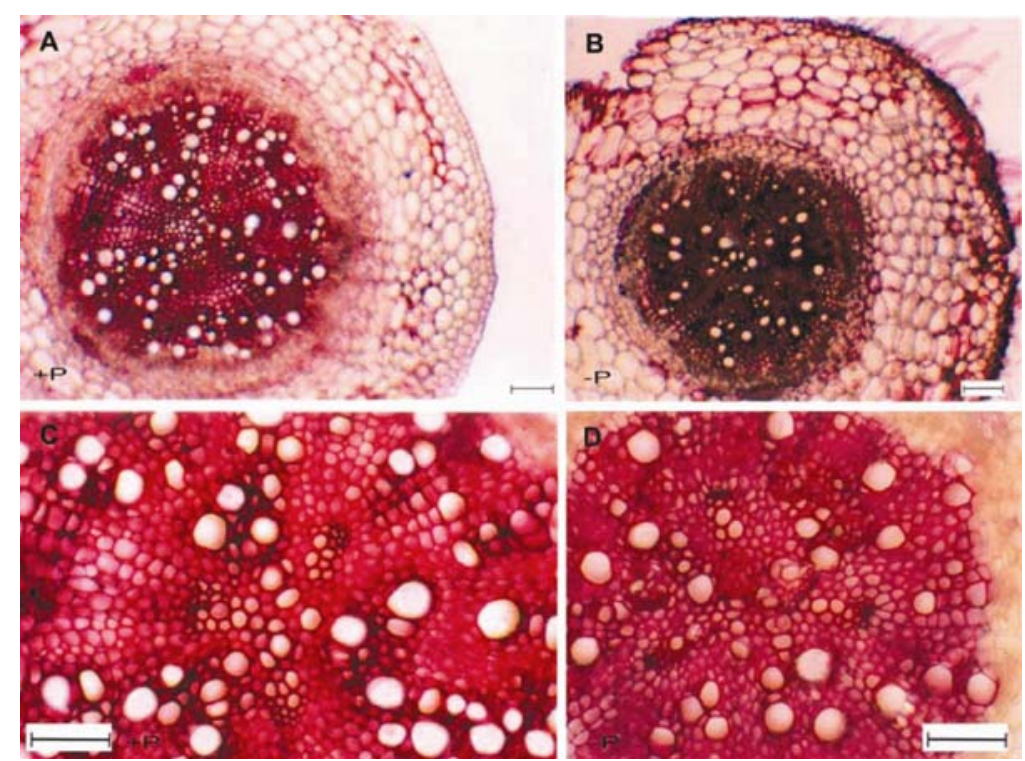

Fig. 1. Transverse sections of root of 28-day-old lentil grown in sand culture containing phosphorus $(+\mathrm{P})(\mathrm{A}, \mathrm{C})$ and no phosphorus $(-\mathrm{P})(\mathrm{B}, \mathrm{D})$. Bar $=100 \mu \mathrm{m}$.

Stem diameter was found to decrease under $-\mathrm{P}$ condition compared to +P (Fig. 2 A, B). This smaller diameter was related with the reduction in cell size and also with reduction in size of the 
vascular elements. A similar result of decreased stem diameter under phosphorus deficiency was also recorded in maize by Lyon and Garcia (1944). Epidermal cells were smaller in -P plant (Fig. 2B) than that of $+\mathrm{P}$ plant (Fig. 2A). The cuticle deposited over the epidermis was thickened in plant grown under phosphorus deficient condition. Cortex consisted of 7 - 8 layers of parenchymatous cells. The cortical cells were larger with intercellular spaces (Fig. 2A) in the plant fed with phosphorus than without phosphorus (Fig. 2B). Two types of vascular bundles were noticed. One type occurred in the stellar region and the other was found in the cortical region where four patches of vascular bundles were found. Conspicuous groups of sclerenchyma were superimposed upon the phloem. Vascular area with vascular elements was declined in phosphorus
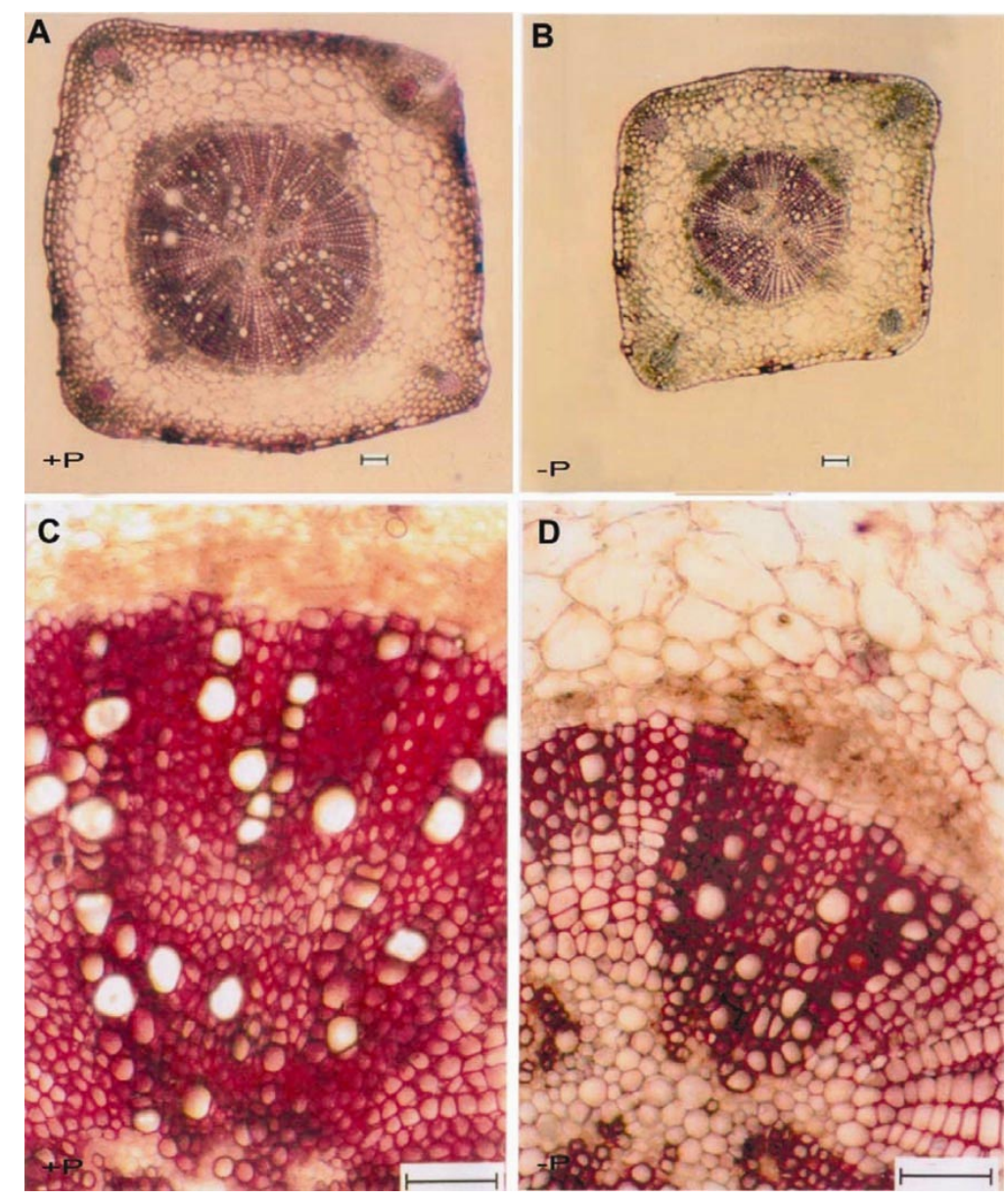

Fig. 2. Transverse sections of internode of 28-day-old lentil grown in sand culture containing phosphorous $(+\mathrm{P})(\mathrm{A}, \mathrm{C})$ and no phosphorous $(-\mathrm{P})(\mathrm{B}, \mathrm{D}) . \mathrm{Bar}=100 \mu \mathrm{m}$.

deficient stem. Numbers of metaxylem and protoxylem vessels under -P were fewer as compared to that of $+\mathrm{P}$ (Fig. 2 C,D). Smaller size of the vessel cavities was noticed under $\mathrm{P}$ deficient condition. Lovelock et al. (2006) found that addition of P to P-deficient dwarf mangroves increased the diameter of xylem vessels and area of conductive xylem tissue of the canopy. Xylem 
ray cells were larger in $\mathrm{P}$ deficient stem than that of $+\mathrm{P}$ plant. In phosphorus deficient plant, pith region was increased compared to that of $+\mathrm{P}$.

Leaf thickness was decreased due to phosphorus deficiency (Fig. 3 A, B). Monika et al. (2005) reported that phosphorus deficiency reduced the leaf thickness in grass. Upper and lower epidermal cell became smaller in size in phosphorus deficient leaf (Fig. 3B). Chiera et al. (2002) showed that the cell size and thickness of epidermal cell were decreased under phosphorus deficient conditions in soybean leaf. In $+\mathrm{P}$ plant, cuticle was thinner than that of $-\mathrm{P}$ plant. Palisade and spongy parenchyma were more chlorophyllous and comparatively larger size in the $+\mathrm{P}$ than that of P deficient plant (Fig. 3 A, B). Phosphorus deficiency limited the leaf size in wheat by producing fewer cells of mesophyll tissue per leaf (Daniel et al. 1998).
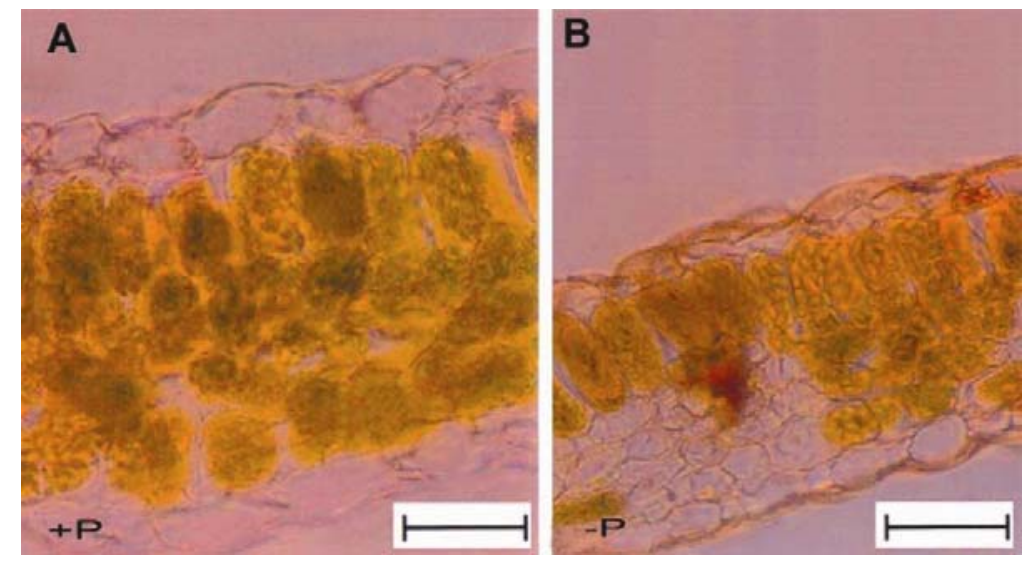

Fig. 3. Transverse sections of the $7^{\text {th }}$ leaf of 28-day-old lentil grown in sand culture containing phosphorus (+P) (A) and no phosphorus (-P) (B). Bar $=100 \mu \mathrm{m}$.

Crop plants are better equipped with an appropriate type of anatomy, largely constitutive in nature, to cope with the surrounding environment (Rieger and Litvin 1999). However, environment also seems to play a major role in modifying the anatomical features. Lentil plants showed different degrees of anatomical changes in the stem, root and leaf under phosphorus deficiency. Modifications of root growth and architecture are the most obvious and bestdocumented responses of plants to P starvation (Raghothama 1999, Williamson et al. 2001). Under P deficient conditions, root diameter decreases and the number of root hairs as well as their length increases which help enhance P uptake by increasing soil surface area contact (Peret $e t a l$. 2011, Brown et al. 2012). Under conditions of P deficiency plants allocate more photosynthate to root production thereby promoting root growth and allowing the root system to explore greater volumes of soil for P (Nielsen et al. 2001). The advantages of this have been demonstrated, for example, in bean (Phaseolus vulgaris) where genotypes with highly branched, actively growing root systems have been shown to be more $\mathrm{P}$ efficient than genotypes lacking such root traits (Lynch and Brown 2001). This has also been confirmed in brassicas (Hammond et al. 2009) and demonstrated for production of lateral roots (Zhu and Lynch 2004). Leaf growth depression under phosphorus deficiency is also well documented (Chiera et al. 2002, Assuero et al. 2004, Kavanová et al. 2006). 


\section{References}

Assuero SG, Mollier A and Pellerin S 2004. The decrease in growth of phosphorus-deficient maize leaves is related to a lower cell production. Plant Cell Environ. 27: 887-895.

Brown LK, George TS, Dupuy LX and White PJ 2012. A conceptual model of root hair ideotypes for future agricultural environments: What combination of traits should be targeted to cope with limited $\mathrm{P}$ availability? Viewpoint: Part of a special issue on matching roots to their environment. Ann. Bot. pp. 114, doi:10.1093/aob/mcs231. www.aob.oxfordjournals.org.

Chandler JN and Bartels D 2008. Drought: Avoidance and adaptation. In: SW Trimble, BA Stewart and TA Howel eds, Encyclopedia of Water Science. Taylor and Francis Group, London. pp. 224.

Chiera J, Thomas J and Rufty T 2002. Leaf initiation and development in soybean under phosphorus stress. J. Exp. Bot. 53: 473-481.

Czarnecki O, Yang J, Weston DJ, Tuskan GA and Chen JG 2013. A dual role of strigolactones in phosphate acquisition and utilization in plants. Int. J. Mol. Sci. 14: 7681-7701.

Daniel R, Keltjens WG and Gourdian F 1998. Plant leaf area expansion and assimilate production in wheat (Triticum aestivum L.) growing under low phosphorus conditions. Plant and Soil 200: 227-240.

Fohse D, Claassen N and Jungk A 1991. Phosphorus efficiency of plants. II. Significance of root radius, root hairs and cation-anion balance for phosphorus influx in seven plant-species. Plant and Soil 132: 261272.

Hammond JP, Broadley MR, White PJ, King GJ, Bowen HC, Hayden R, Meacham MC, Mead A, Overs T, Spracklen WP and Greenwood DJ 2009. Shoot yield drives phosphorus use efficiency in Brassica oleracea and correlates with root architectural traits. J. Exp. Bot. 60: 1953-1968.

Hewitt EJ 1966. Sand and water culture methods used in the study of plant nutrition. Farnham Royal, England: Commonwealth Agricultural Bureau. Technical Communication No. 22 (Revised $2^{\text {nd }}$ ed.) of the Commonwealth Bureau of Horticulture and Plantation Crops, East Malling, Maidstone, Kent. 547 p.

Hoagland DR and Arnon DI 1950. The water-culture method for growing plants without soil. Circular 347, Univ. of Calif. Agric. Exp. Station, Berkeley. 31 p.

Kavanová M, Lattanzi FA, Grimoldi AA and Schnyder H 2006. Phosphorus deficiency decreases cell division and elongation in grass leaves. Plant Physiol. 141: 766-775.

Li FH, Pan XH, Liu SY, Li MY and Yang FS 2004. Effect of phosphorus deficiency stress on root morphology and nutrient absorption of rice cultivars. Acta Agronomica Sinica 30: 438-442.

Liu HC, Chen GJ, Chen RY, Kuang YH and Wu XY 2004. Anatomical structures of seedlings of Vigna unguiculata ssp. sesquipedalis cultivars under phosphorus deficiency stress. J. Plant Resour. Environ. 3: 48-52.

Lovelock CE, Ball MC, Choat B, Engelbercht BMJ, Holbrook NM and Feller IC 2006. Linking physiological processes with mangrove forest structure: Phosphorus deficiency limits canopy development, hydraulic conductivity and photosynthetic carbon gain in dwarf Rhizophora mangle. Plant Cell Environ. 29: 793802.

Lynch JP and Brown KM 2001. Topsoil foraging: an architectural adaptation of plants to low phosphorus availability. Plant and Soil 237: 225-237.

Lyon CB and Garcia CR 1944. Anatomical responses of tomato stems to variation on the macronutrient anion supply. Bot. Gaz. 105: 394-405.

Monika KA, Affredo LF, Alberdo GA and Hans S 2005. Phosphorus deficiency decreases cell division and elongation in grass. Plant Physiol. 141: 766-775.

Nielsen KL, Eshel A and Lynch JP 2001. The effect of phosphorus availability on the carbon economy of contrasting common bean (Phaseolus vulgaris L.) genotypes. J. Exp. Bot. 52: 329-339.

Peret B, Clement M, Nussaume L and Desnos T 2011. Root developmental adaptation to phosphate starvation: Better safe than sorry. Trends Plant Sci. 16: 442-450.

Raghothama KG 1999. Phosphate acquisition. Annu. Rev. Plant Physiol. 50: 665-693.

Rieger M and Litvin P 1999. Root system hydraulic conductivity in species with contrasting root anatomy. J. Exp. Bot. 50: 201-209. 
Runge-Metzger A 1995. Closing the cycle: Obstacles to efficient P management for improved global security. In: Teissen H. ed. Phosphorus in the Global Environment: Transfers, Cycles and Management. Chichester: Wiley \& Sons Ltd., pp. 27-42.

Stutter MI, Shand CA, George TS, Blackwell MSA, Bol R, Mackay RL, Richardson AE, Condron LM, Turner BL and Haygrath PM 2012. Recovering phosphorus from soil: a root solution? Environ. Sci. Technol. 46: 1977-1978.

Uddin J, Sarker A, Podder R, Afzal A, Rashid H and Siddique KHM 2008. Development of new lentil varieties in Bangladesh. "Global Issues. Paddock Action." Edited by M. Unkovich. Proc. 14th Agron. Conf. 21-25 September 2008, Adelaide, South Australia.

White PJ and Brown PH 2010. Plant nutrition for sustainable development and global health. Ann. Bot. 105: 1073-1080.

Williamson LC, Ribrioux SPCP, Fitter AH and Leyser HMO 2001. Phosphate availability regulates root system architecture in Arabidopsis. Plant Physiol. 126: 875-882.

Zhu JM and Lynch JP 2004. The contribution of lateral rooting to phosphorus acquisition efficiency in maize (Zea mays) seedlings. Functional Plant Biol. 31: 949-958.

(Manuscript received on 31 October, 2013; revised on 3 July, 2014) 